\title{
LABORATORY SCALE INVESTIGATION INTO THE CORROSION OF COPPER IN A SULPHUR-CONTAINING ENVIRONMENT
}

\author{
BM Thethwayo $^{1}$ and AM Garbers-Craig ${ }^{2}$
}

1: Postgraduate student, Department of Materials Science and Metallurgical Engineering, University of Pretoria, Pretoria, South Africa, 0002. mpilot@tuks.co.za

2: Associate Professor, Department of Materials Science and Metallurgical Engineering, University of Pretoria, Pretoria, South Africa, 0002. Corresponding author. Tel: +27 12-420-3189, Fax: +27 12-362-5304, Andrie.Garbers-Craig@up.ac.za

\begin{abstract}
$\underline{\text { Abstract }}$
The effect of temperature and gas composition on the corrosion rate and corrosion byproduct of copper foil was studied by exposing it to sulphur $\left(\mathrm{S}_{2}\right), \mathrm{S}_{2}+$ hydrochloric acid $(\mathrm{HCl})$ and hydrogen sulphide. The temperature was varied from 80 to $140{ }^{\circ} \mathrm{C}$. Copper foil reacted with $\mathrm{S}_{2}$ to form $\mathrm{CuS}, \mathrm{Cu}_{9} \mathrm{~S}_{8}$ and $\mathrm{Cu}_{1.8} \mathrm{~S}$. Corrosion rates ranged from $9.6 \mu \mathrm{m} / \mathrm{h}$ at $110{ }^{\circ} \mathrm{C}$ to $0.5 \mu \mathrm{m} / \mathrm{h}$ at $140{ }^{\circ} \mathrm{C}$. The presence of $\mathrm{HCl}$ caused pitting and enhanced the corrosion rate above $112{ }^{\circ} \mathrm{C} . \mathrm{Cu}_{2} \mathrm{~S}$ formed when copper was exposed to hydrogen sulphide gas. Sulphide scale that formed was friable and nonadherent.
\end{abstract}

Keywords: A-copper, C-sulphidation, C-corrosion

\section{Introduction}

PGM (platinum group metal) smelters typically use copper waffle coolers to extract heat from the refractory wall. Corrosion of these copper coolers is a major concern in all PGM smelters that treat sulphide concentrates, as corrosion rates of greater than 60 $\mathrm{mm} / \mathrm{y}$ have been observed at the slag-charge interface level in the smelter $[1,2,3]$. During the smelting of PGM-containing sulphide ores gases such as sulphur vapour, sulphur dioxide, water vapour and chlorine gas are given off $[4,5]$. The source of the sulphur vapour is sulphides and labile sulphur contained in the feed [4]. Chlorine gas originates from the dissociation of halides such as $\mathrm{KClMg}\left(\mathrm{SO}_{4}\right)$ and $\mathrm{KMgCl}_{3}$ which can potentially be present in the feed [5]. Water vapour comes from the moisture [6] and chemically bound water in the feed material [7]. Water vapour dissociates to oxygen and hydrogen at high temperatures. The hydrogen can then react with other gases such as sulphur and chlorine to form hydrogen sulphide and hydrogen chloride gas [8]. High temperatures associated with the smelting process drive these gases towards a cooler place, which is in front of the copper coolers [5]. Reaction between these gases and the copper coolers result in the corrosion and subsequent consumption of the copper coolers. 
A post-mortem analysis of refractory samples that were in contact with a corroded copper cooler indicated that elemental sulphur, base metal sulphides and $\mathrm{CuS}$ are associated with the copper cooler [9]. Wear of the copper cooler proceeded through reaction between the copper and base metal sulphides, as well as gaseous attack of copper mainly by sulphur gas.

Virtually no published data is available on the mechanism by which copper coolers corrode in PGM smelters. A number of authors have however, studied phase relations between copper and sulphur, chlorine and $\mathrm{H}_{2} \mathrm{~S}$ at low temperatures [10-22].

Bartkowicz and Stoklosa established that the sulphidation of copper between $97^{\circ} \mathrm{C}$ and $150{ }^{\circ} \mathrm{C}$ is complex, with the formation of hexagonal chalcocite $\left(\mathrm{Cu}_{2} \mathrm{~S}\right)$, monoclinic chalcocite $\left(\mathrm{Cu}_{2} \mathrm{~S}\right)$ and covellite $(\mathrm{CuS})$ [12]. Blachnik and Muller reported that covellite and $\mathrm{Cu}_{1.1} \mathrm{~S}$ form below $128^{\circ} \mathrm{C}$, while between $128^{\circ} \mathrm{C}$ and $150{ }^{\circ} \mathrm{C}$ covellite (outer layer) and $\mathrm{Cu}_{1.8} \mathrm{~S}$ (inner layer) form when a copper foil is exposed to sulphur [13]. They also observed that the layer of sulphide scale that formed is porous and poorly adhered to the metallic core [13]. Covellite is in equilibrium with sulphur below $507^{\circ} \mathrm{C}$, while $\mathrm{Cu}_{2} \mathrm{~S}$ is in equilibrium with copper according to the phase diagram by Vaughan and Craig (Figure 1, [18]). It can therefore be expected that when a copper foil is exposed to sulphur at temperatures below $150{ }^{\circ} \mathrm{C}$, an outer layer of covellite $(\mathrm{CuS})$ will form, while an inner layer of chalcocite $\left(\mathrm{Cu}_{2} \mathrm{~S}\right)$ will form on the metal surface. Covellite and chalcocite are therefore the sulphide phases that are expected to be associated with copper coolers when sulphide ores are smelted.

Figure 1: Temperature-composition diagram of condensed phases in the CopperSulphur system [18].

There is general agreement that chalcocite forms by the outward diffusion of copper ions when copper is exposed to hydrogen sulphide gas [10,14-16], and that the rate of growth of chalcocite is enhanced by an increase in temperature [17].

$\mathrm{CuCl}$ is reported to be the main phase that forms when copper is exposed to hydrogen chloride gas $[19,20]$. Chlorine has the ability to diffuse through the corrosion layer, providing a path for metal ion diffusion to the reaction surface. Chlorine therefore increases the corrosion rate by physically disrupting the protective scale [20-22]. The objective of this study was to determine how the surface temperature of copper and the composition of the corrosive gases affect the corrosion rate of copper, as well as the phase compositions and morphologies of the corrosion products. Laboratory scale corrosion tests were executed where the conditions that prevail on the surface of the copper cooler were simulated. Copper foil was exposed to sulphur vapour, sulphur vapour with hydrogen chloride gas, sulphur vapour with water vapour, and hydrogen sulphide gas. The laboratory scale corrosion tests were performed from $80{ }^{\circ} \mathrm{C}$ to 140 ${ }^{\circ} \mathrm{C}$. This temperature range was chosen based on heat flux calculations through the wall of a PGM smelter [9].

\section{Material and methods}

\subsection{Apparatus}

Annealed $99.7 \%$ copper foil ${ }^{*}$ (thickness of $0.05 \mathrm{~mm}$, width of $2.5 \mathrm{~mm}$ and length of $60 \mathrm{~mm}$ ) was cut out of a copper sheet and used as the substrate. The samples were

\footnotetext{
* Supplied by Industrial Analytical, with typical analysis (ppm): $\mathrm{Ag}<100, \mathrm{Al}<100, \mathrm{~B}<10, \mathrm{Ca} 30$, $\mathrm{Fe}<500, \mathrm{Mg}<10, \mathrm{Ni}<300, \mathrm{~Pb}<100, \mathrm{Si} 10, \mathrm{Sn}<100, \mathrm{Zn} 100$.
} 
subsequently abraded mechanically using a silicone carbide paper to size $400 \mu \mathrm{m}$. Fibre glass tinned copper wires were soldered to each end of the copper foil for electrical connections. A Goodwill power supply (GPR 1850) was used as a current source. Shielded cables were used to complete the electrical circuit between the electrical instruments and the tinned copper wires from the foil. The foil was attached to a heat sink (hollow copper block of dimensions $70 \mathrm{~mm} \times 20 \mathrm{~mm} \times 20 \mathrm{~mm}$ with a $10 \mathrm{~cm}$ inner diameter, which was connected to a Labcon CPM 200 silicone oil bath). The silicone oil was circulated through the heat sink in order to regulate the temperature of the copper foil. A type $\mathrm{K}$ thermocouple was fitted onto the heat sink to measure the temperature of the copper foil. A sealable glass jar was used as a reaction chamber, through which different gaseous species were purged. A Heidolph MR2002 hot plate was used to heat a sublimed sulphur powder (Merck Chemicals) to above $200{ }^{\circ} \mathrm{C}$, to ensure the reaction chamber remained saturated with sulphur vapour. Argon (carrier gas) was bubbled through concentrated (32\%v/v) hydrochloric acid to generate hydrogen chloride gas. Hydrogen sulphide gas was produced by reacting 124 $\mathrm{ml}$ of $0.15 \mathrm{~mol} / \mathrm{L}$ sulphuric acid with $10 \mathrm{~g}$ of iron sulphide $(\mathrm{FeS})$ which theoretically produced $19.35 \mathrm{~g}$ of hydrogen sulphide gas according to the reaction model of FactSage [9]. Redox titrations were performed to confirm the amount of hydrogen sulphide gas that formed [23].

\subsection{Experimental procedure}

A copper foil mounted onto the heat sink was heated to the operating temperature under an argon atmosphere to avoid pre-sulphidation and oxidation of the foil. Upon reaching the operating temperature the copper foil was suspended in a sealed $3 \mathrm{~L}$ glass reactor containing the corrosive gas. Argon $(99.9 \%$ ) at a flowrate of $0.25 \mathrm{~L} / \mathrm{min}$ was used as a carrier gas. All the corrosion tests were performed in triplicate.

\subsection{Calculation of corrosion rates}

An electrical resistance technique was employed to determine the corrosion rate of the copper foil. The change in foil resistance was measured using a four wire resistance measurement in which a wire of known resistance (shunt resistor) was connected in series with the copper foil and a current supply. The voltage drop across the shunt resistor was used to calculate the current flow through the circuit. The calculated current and the voltage drop across the copper foil was then used to calculate the resistance of the copper using Ohm's law (V=IR) [24].

A digital multimeter (Datataker DT80) with built-in sensors and data logger was used for data acquisition (voltage and temperature). The change in foil thickness was calculated from Equation 1, where R is the electrical resistance, $\rho$ is the electrical resistivity, $\mathrm{L}$ is the electrical length, $\mathrm{A}$ is the cross-sectional area, $\mathrm{t}$ is the thickness and $\mathrm{w}$ is the width of the foil [25]:

$$
R=\frac{\rho L}{A}=\frac{\rho L}{t w}
$$

\section{Equation 1}

The length and width of the foil was assumed to be constant and the resistivity was calculated using Equation 2, where alpha $(\alpha)$ is the temperature coefficient of resistivity which accounts for the change in resistivity due to temperature [24, 25]: 
Alpha $(\alpha)$ of the copper foil was determined by heating foil from $25^{\circ} \mathrm{C}$ to $140^{\circ} \mathrm{C}$ in an argon atmosphere. The slope of $\mathrm{R} / \mathrm{R}_{0}$ vs. $\mathrm{dT}$ gave an alpha value of $0.0031 \mathrm{~K}^{-1}$. The change in foil thickness was plotted against time at constant temperature to determine the corrosion rate.

\subsection{Determination of morphology and phase composition of the corrosion products} Upon completion of each experiment the copper foil was allowed to cool to room temperature under an argon atmosphere. The cooled copper foil residue and corrosion scale were subsequently analysed to determine the effect of temperature and gas composition on the morphology and phase composition of the corrosion product. This was done by performing XRD and SEM-EDS analyses, using a PANanalytical X'pert Pro powder diffractometer with $\mathrm{X}$ 'celerator detector and $\mathrm{Fe}$ filtered $\mathrm{Co}-\mathrm{K} \alpha$ radiation, and a Jeol JSM 6300 scanning electron microscope.

\section{Results and Discussion}

\subsection{Corrosion of copper by sulphur vapour}

3.1.1. Effect of temperature

Copper foil samples were exposed to sulphur vapour for 1 hour at temperatures in the range $65{ }^{\circ} \mathrm{C}$ to $140{ }^{\circ} \mathrm{C}$ to investigate the effect of temperature on the corrosion rate. The observed average corrosion rates of copper foil exposed to sulphur vapour were $3.1 \mu \mathrm{m} / \mathrm{h}$ at $65^{\circ} \mathrm{C}, 6.2 \mu \mathrm{m} / \mathrm{h}$ at $80^{\circ} \mathrm{C}, 6.5 \mu \mathrm{m} / \mathrm{h}$ at $90{ }^{\circ} \mathrm{C}, 8.5 \mu \mathrm{m} / \mathrm{h}$ at $100{ }^{\circ} \mathrm{C}, 9.2$ $\mu \mathrm{m} / \mathrm{h}$ at $110^{\circ} \mathrm{C}$ and $0.3 \mu \mathrm{m} / \mathrm{h}$ from $120^{\circ} \mathrm{C}$ to $140{ }^{\circ} \mathrm{C}$ (Figures 2 and 3 ).

Figure 2: Average corrosion rate as a function of temperature when copper was exposed to sulphur vapour in the temperature range $65^{\circ} \mathrm{C}$ to $140^{\circ} \mathrm{C}$ for 1 hour.

Figure 3: Thickness loss on copper foil as a function of exposure time for temperatures ranging from $65^{\circ} \mathrm{C}$ to $140{ }^{\circ} \mathrm{C}$ (sulphidation by sulphur vapour).

The corrosion rate of copper exposed to sulphur vapour for 1 hour increased as the exposure temperature increased from $65^{\circ} \mathrm{C}$ to $110^{\circ} \mathrm{C}$, while above $110^{\circ} \mathrm{C}$ the corrosion rate decreased significantly. The decrease in corrosion rate could be attributed to the formation of a porous layer on the metal surface, similar to what was observed by Blachnik et al. [13]. Linear corrosion rate behaviour was observed in short exposure times (Figure 3), although there were minor variations during the initial 20 minutes of the test, which could have been caused by physical disruptions of the scale. To determine the transition temperature from high corrosion rates (below $110^{\circ} \mathrm{C}$ ) to low corrosion rates (above $110^{\circ} \mathrm{C}$ ) three experiments were performed where the substrate temperature was increased from $80^{\circ} \mathrm{C}$ to $140{ }^{\circ} \mathrm{C}$ at $20{ }^{\circ} \mathrm{C}$ per hour. The aim of this test was to determine how fluctuating operating temperatures in the smelter would affect the corrosion of the copper coolers. Thickness loss versus exposure time for the first test is depicted in Figure 4. The transition temperature from fast to slow corrosion rates was $112{ }^{\circ} \mathrm{C}$ in the first and second test, while in the third test the transition occurred at $113{ }^{\circ} \mathrm{C}$. The total thickness loss of the copper foil at the corrosion rate transition point was respectively $14.5 \mu \mathrm{m}, 20.2 \mu \mathrm{m}$ and $11.45 \mu \mathrm{m}$ for the first, second and third tests. Transition from high to low corrosion rates could therefore be linked to temperature. 
Figure 4: Thickness loss of copper foil as a function of exposure time in the temperature range $80^{\circ} \mathrm{C}$ to $140{ }^{\circ} \mathrm{C}$ in sulphur vapour.

The change in corrosion rate observed between $112{ }^{\circ} \mathrm{C}$ and $114{ }^{\circ} \mathrm{C}$ coincides with the melting point of sulphur (which varies from $110^{\circ} \mathrm{C}$ to $112{ }^{\circ} \mathrm{C}$ for $\alpha$-sulphur, and is reported to be $114^{\circ} \mathrm{C}$ for $\beta$-sulphur [18]). A slower corrosion rate can also be attributed to the porous sulphide layer that formed on the metal-scale interface, which poorly adhered to the metal. Poorly adhered corrosion scale can retard the diffusion of copper species to the surface for the reaction to proceed, leading to slower corrosion rates $[12,26]$. Dravnieks et al. [26] explained that when a metal is covered with an oxide layer which is in contact with an oxidising gas, the oxidation of the metal will proceed by diffusion of metal through the oxide layer. With decreasing direct contact between the metal and oxide the supply of metal to the bulk of the scale is slowed down, and corrosion rates decrease. The porous sulphide layer underneath the thick solid layer of sulphur can therefore hamper the diffusion of copper to the reaction site where sulphidation takes place.

The high corrosion rates observed below $110^{\circ} \mathrm{C}$ demonstrate that the sulphide scale that formed was not protective.

\subsubsection{Effect of exposure time at $140{ }^{\circ} \mathrm{C}$}

Copper foil at $140{ }^{\circ} \mathrm{C}$ was exposed to sulphur vapour for 8 hours to ascertain the effect of long exposure times on the corrosion rate (Figure 5). An initial average corrosion rate of $0.11 \mu \mathrm{m} / \mathrm{h}$ was observed in the first five hours of exposure of the first corrosion test. A sudden increase in corrosion rate was observed between the $294^{\text {th }}$ minute and $356^{\text {th }}$ minute while the temperature remained constant (indicated by arrows in Figure 5). During this period a total of 1.22 micron was lost in an hour which was about 10 times higher than the initial corrosion rate. The corrosion rate decreased sharply to $0.09 \mu \mathrm{m} / \mathrm{h}$ for the remainder of the test. After the test a crack was observed in the corrosion product. The sudden increase in corrosion rate could therefore be attributed to the crack which exposed fresh copper to the corrosive gases. The two other replicates of this test depicted parabolic rate behaviour, and no cracks were observed in the corrosion product. Each of the three tests would display unique effects which is typical of what might happen with long exposure times, as in the PGM smelter.

Figure 5: Thickness loss of a copper foil as a function of exposure time at $140^{\circ} \mathrm{C}$ in sulphur vapour.

Other factors affecting corrosion behaviour of a scale includes morphology of the corrosion product (porosity, grain size and permeability), loss of the protective layer due to poor adherence [15], defects [22] and internal stresses which lead to crack formation [11]. These factors may induce linear rate growth of the corrosion layer at long exposure times. Tests performed under synthetic conditions can therefore not be extrapolated to longer reaction times (as under plant conditions) since sulphidation kinetics can change over time, depending on the morphology of the sulphide scale, and the disruption thereof [11].

\subsection{Corrosion of copper by sulphur vapour and hydrogen chloride gas}

Copper foil was exposed to both sulphur vapour and hydrogen chloride gas at $80{ }^{\circ} \mathrm{C}$, $110{ }^{\circ} \mathrm{C}$ and $140{ }^{\circ} \mathrm{C}$, to determine the effect of hydrogen chloride gas addition on 
sulphidation. At $80{ }^{\circ} \mathrm{C}$ parabolic rate behaviour was observed, with a thickness loss rate that decreased from $0.07 \mu \mathrm{m} / \mathrm{min}$ in the first hour to $0.02 \mu \mathrm{m} / \mathrm{min}$ at the end of the second hour. This parabolic rate behaviour observed at $80^{\circ} \mathrm{C}$ can presumably be attributed to the critical thickness effect observed by Reid and co-workers [22]. According to these authors the rate of film growth becomes parabolic when the corrosion product reaches a critical thickness, which indicates that diffusion of copper through the corrosion layer becomes rate-limiting as the corrosion scale becomes thicker.

A linear corrosion rate of $0.07 \mu \mathrm{m} / \mathrm{min}$ was observed at $115{ }^{\circ} \mathrm{C}$ in the initial 90 minutes after which the slope increased to $0.16 \mu \mathrm{m} / \mathrm{min}$. The cause of the increase in corrosion rate is not clear. An average corrosion rate of $0.19 \mu \mathrm{m} / \mathrm{min}$ was observed when the temperature of the copper foil was $140^{\circ} \mathrm{C}$.

Faster corrosion rates at $140{ }^{\circ} \mathrm{C}$ compared to $80^{\circ} \mathrm{C}$ and $115^{\circ} \mathrm{C}$ can be attributed to the ability of the hydrogen chloride gas to penetrate through the corrosion layer at higher temperatures $[21,22]$. Differences in morphology of the corrosion products that form at these temperatures $\left(80^{\circ} \mathrm{C}\right.$ to $\left.140^{\circ} \mathrm{C}\right)$, may also influence the corrosion behaviour of the copper foil since chlorine diffuse faster in chalcocite than in covellite [27]. Copper foils were also exposed to a mixture of sulphur vapour and hydrogen chloride gas where the copper foil temperature was gradually raised from $80{ }^{\circ} \mathrm{C}$ to $140{ }^{\circ} \mathrm{C}$ at $20^{\circ} \mathrm{C}$ intervals to determine the transition temperature from a slow corrosion rate (at $80{ }^{\circ} \mathrm{C}$ and $110^{\circ} \mathrm{C}$ ) to a fast corrosion rate (at $140^{\circ} \mathrm{C}$ ). The thickness loss versus time graph for the first test is depicted in Figure 6. The transition temperature was $112^{\circ} \mathrm{C}$ in both the first and the second test. The total thickness loss was respectively 10.74 $\mu \mathrm{m}$ and $19.8 \mu \mathrm{m}$ at this transition temperature. It was again observed that temperature strongly influences the corrosion rate. In the presence of hydrogen chloride gas the corrosion changed from a slow rate to a high rate at $112^{\circ} \mathrm{C}$, while in sulphur vapour the corrosion rate changed from a high rate to a low rate at $112^{\circ} \mathrm{C}$.

Figure 6: Thickness loss as a function of exposure time at varying temperatures (80 ${ }^{\circ} \mathrm{C}$ to $140{ }^{\circ} \mathrm{C}$ ) when copper foil was exposed to both sulphur vapour and hydrogen chloride gas.

It is presumed that the sulphide layer that forms above $110{ }^{\circ} \mathrm{C}$ is passivating to sulphur, but the presence of chlorine enables the corrosive gases and metal ions to diffuse to the reaction site, thereby enhancing corrosion. In the presence of hydrogen chloride gas the corrosion rate of copper by sulphur can be enhanced to above 100 $\mathrm{mm} / \mathrm{y}$ if the copper surface temperature is above $110^{\circ} \mathrm{C}$. This agrees with the work of Tran et al. [11], who reported that foil cleaned with hydrogen chloride reacted faster at temperatures above the melting point of sulphur, compared to foil cleaned with alcohol. It can therefore be concluded that the transition from a slower to a faster corrosion rate is associated with the melting of the sulphur, and the ability of chlorine to permeate through a thick layer of molten sulphur and sulphide phases. The observed increase in corrosion rate at $142{ }^{\circ} \mathrm{C}$ was presumably caused by cracks and defects in the foil since they could not be attributed to any phase transformations or the formation of any additional phases.

\subsection{Corrosion of copper by hydrogen sulphide gas}

Copper foil was also exposed to hydrogen sulphide gas at $80^{\circ} \mathrm{C}, 110^{\circ} \mathrm{C}$, and $140^{\circ} \mathrm{C}$ for 110 minutes. Average corrosion rates at these temperatures were respectively $0.003 \mu \mathrm{m} / \mathrm{min}, 0.01 \mu \mathrm{m} / \mathrm{min}$ and $0.08 \mu \mathrm{m} / \mathrm{min}$. The corrosion rate of copper by 
hydrogen sulphide gas therefore increases with temperature, similar to what Tran and co-workers observed [17].

\subsection{Morphology and phase composition of the corrosion products}

\subsubsection{Copper exposed to sulphur vapour}

BSE images of the corrosion products that formed when copper foil was exposed to sulphur vapour at different temperatures are depicted in Figure 7. A black corrosion product formed at $80^{\circ} \mathrm{C}(\mathrm{Fig}$. 7a), which contained fine yellow particles at the gasscale interface. Covellite and synthetic sulphur were detected by XRD as major phases in this corrosion product. This phase composition was confirmed by EDS analysis.

Figure 7: BSE images of the cross section of the corrosion product formed during sulphidation with sulphur vapour at a) $80^{\circ} \mathrm{C}$, b) $110^{\circ} \mathrm{C}$, c) $140{ }^{\circ} \mathrm{C}$ and d) $80^{\circ} \mathrm{C}-140$ ${ }^{\circ} \mathrm{C}$.

A black non-adherent layer was formed after exposing the copper foil to sulphur at $110{ }^{\circ} \mathrm{C}$ (Fig. $\left.7 \mathrm{~b}\right)$. Covellite and digenite $\left(\mathrm{Cu}_{9} \mathrm{~S}_{5}\right)$ were detected by XRD as major phases. A dense uniform copper sulphide with a $\mathrm{Cu}$ :S atomic ratio of 1 (covellite) was detected by EDS at the gas-scale interface. Meaningful EDS analysis of a porous copper rich sulphide layer adjacent to the copper foil could not be determined due to the high porosity of this layer. However, the stoichiometry of this phase is close to that of yarrowite $\left(\mathrm{Cu}_{9} \mathrm{~S}_{8}\right)$.

The corrosion product after exposure of a copper foil to sulphur vapour at $140{ }^{\circ} \mathrm{C}$ consisted of a thick deep red layer at the gas-scale interface (Fig. 7c). Yarrowite, covellite and sulphur were detected by XRD as major phases with digenite as a minor phase. EDS detected the outer layer to be sulphur, followed by a porous non-adherent copper sulphide layer in between the sulphur and copper layers, with a stoichiometry close to that of yarrowite.

It is assumed that the apparent deviation from stoichiometry when the sulphide layers that formed at $110^{\circ} \mathrm{C}$ and $140^{\circ} \mathrm{C}$ were analysed by EDS, is due to a mixture of very finely divided and intergrown sulphides such as digenite, covellite and yarrowite, similar to what was reported by Blachnik et al. [13].

The effect of temperature variation on the morphology of the corrosion products was examined by exposing a copper foil to sulphur and increasing its temperature from 80 ${ }^{\circ} \mathrm{C}$ to $140{ }^{\circ} \mathrm{C}$. A poorly adherent corrosion product formed under these conditions, with a thick red layer at the gas-scale interface (Fig. 7d). Covellite and sulphur were detected by XRD as the major phases. According to the EDS analysis a sulphur layer formed at the gas-scale interface. A dendritic copper sulphide with the stoichiometry of covellite could be distinguished adjacent to this sulphur layer, followed by a smooth, dense and uniform layer of covellite with cracks parallel to the foil surface, adjacent to the copper foil. Varying the copper foil surface temperature from $80{ }^{\circ} \mathrm{C}$ to $140{ }^{\circ} \mathrm{C}$ therefore affects the morphology and phase composition of the corrosion product, and favours the formation of covellite.

\subsubsection{Copper exposed to sulphur vapour with hydrogen chloride gas at $140{ }^{\circ} \mathrm{C}$}

The copper foil residue was perforated and heavily pitted after exposure to a mixture of sulphur vapour and hydrogen chloride gas at $140{ }^{\circ} \mathrm{C}$ (Figure 8). Covellite (CuS) and elemental sulphur $(\mathrm{S})$ were detected by XRD analysis in this corrosion product. A 
copper sulphide layer with a $\mathrm{Cu}: \mathrm{S}$ atomic ratio of 1 (covellite) was detected by EDS. Hydrogen chloride gas addition at $140{ }^{\circ} \mathrm{C}$ changed the phase composition of the sulphide from a mixture of yarrowite, covellite and digenite to only covellite. The presence of hydrogen chloride therefore increased the average sulphur content of the sulphide scale that formed.

When varying the temperature from $80{ }^{\circ} \mathrm{C}$ to $140{ }^{\circ} \mathrm{C}$ two layers were identified by EDS: A sulphur layer at the gas-scale interface and covellite with small amounts of chlorine on the metal-scale interface. XRD detected $\alpha$-sulphur, covellite and minor amounts of tolbachite $\left(\mathrm{CuCl}_{2}\right)$. The phase composition of the corrosion product at 80 ${ }^{\circ} \mathrm{C}$ to $140{ }^{\circ} \mathrm{C}$ is different to that observed at $140{ }^{\circ} \mathrm{C}$ in that chloride phases were not detected at $140{ }^{\circ} \mathrm{C}$.

Figure 8: BSE image of the cross-section of the copper foil after exposure to both sulphur vapour and hydrogen chloride gas at $140^{\circ} \mathrm{C}$.

\subsubsection{Copper exposed to sulphur vapour with water vapour at $80^{\circ} \mathrm{C}$ to $140{ }^{\circ} \mathrm{C}$}

Covellite, $\alpha$-sulphur and dolerophane $\left(\mathrm{Cu}_{2} \mathrm{O}\left(\mathrm{SO}_{4}\right)\right)$ were detected by XRD as major phases that formed when copper was exposed to both sulphur vapour and water vapour. Two layers with non-stoichiometric compositions could be distinguished by EDS: a porous inner layer and a dendrite-structured layer at the gas-scale interface. The inner layer consisted of a non-stoichiometric copper oxysulphate phase. The dendrites are $\mathrm{Cu}-\mathrm{S}-\mathrm{O}-$ based with a $\mathrm{Cu}: \mathrm{S}$ atomic ratio of 1 , and contains $13 \mathrm{wt} \%$ oxygen (Figure 9). Copper oxide did not form. This presumably is due to the sulphur that absorbed onto the copper surface and limited the sites for hydroxyl ions, which are required for metal oxide formation when water vapour is present [28].

Figure 9: BSE image of the corrosion product which formed when copper was reacted from $80^{\circ} \mathrm{C}$ to $140^{\circ} \mathrm{C}$ in a sulphur vapour and water vapour atmosphere.

\subsubsection{Copper exposed to hydrogen sulphide gas}

An adherent sulphide scale was observed when copper foil was exposed to hydrogen sulphide gas at $140^{\circ} \mathrm{C}$. The foil was pitted adjacent to the sulphide scale (Figure 10). The sulphide scale consisted of high and low chalcocite according to the XRD analysis. The stoichiometry of the sulphide was confirmed by EDS to be $\mathrm{Cu}_{2} \mathrm{~S}$. These findings are in agreement with the observation reported in the literature that chalcocite is the sulphide phase which forms when copper reacts with hydrogen sulphide gas $[11,12,14,15]$.

The temperature of the copper foil was varied from $80{ }^{\circ} \mathrm{C}$ to $140{ }^{\circ} \mathrm{C}$ to examine the effect of varying temperature on the phase composition of the corrosion product. Low and high chalcocite were major phases detected by XRD with minor amounts of covellite. A mixture of $\mathrm{CuS}$ and $\mathrm{Cu}_{9} \mathrm{~S}_{8}$ was detected by EDS as the constituent of this corrosion product. The significant difference in phase composition is that only $\mathrm{Cu}_{2} \mathrm{~S}$ was detected in the sample produced at $140^{\circ} \mathrm{C}$, while $\mathrm{CuS}$ and $\mathrm{Cu}_{9} \mathrm{~S}_{8}$ were also detected in copper foil that was heated from $80{ }^{\circ} \mathrm{C}$ to $140{ }^{\circ} \mathrm{C}$.

Figure 10: BSE image of a cross-section of the copper foil after exposure to hydrogen sulphide gas at $140{ }^{\circ} \mathrm{C}$. 


\section{Conclusions}

A summary of the phases that were detected in the corrosion products are listed in Table 1.

$\mathrm{CuS}$ was the main sulphide phase that formed when copper foil and sulphur reacted at $80{ }^{\circ} \mathrm{C}, 110^{\circ} \mathrm{C}$ and $140^{\circ} \mathrm{C}$. The amount of $\mathrm{CuS}$ that formed decreased as the sulphidation temperature increased from $80{ }^{\circ} \mathrm{C}$ to $140{ }^{\circ} \mathrm{C}$. CuS was the major phase at $80^{\circ} \mathrm{C}$ with sulphur powder at the gas-scale interface. $\mathrm{CuS}$ was observed together with $\mathrm{Cu}_{9} \mathrm{~S}_{5}$ adjacent to the foil at $110^{\circ} \mathrm{C}$, while no sulphur was associated with this corrosion product. $\mathrm{Cu}_{9} \mathrm{~S}_{8}$ was the major phase observed at $140{ }^{\circ} \mathrm{C}$, together with a layer of molten sulphur at the gas-scale interface. Below the melting point of sulphur $\left(112{ }^{\circ} \mathrm{C}\right)$ sulphur gas reacted with copper to form $\mathrm{CuS}$ and sulphur powder at the gasscale interface. Above the melting point of sulphur a porous copper rich sulphide layer formed adjacent to the copper foil, with a layer of molten sulphur at the gasscale interface.

When copper foil at $140{ }^{\circ} \mathrm{C}$ was exposed to sulphur and either hydrogen chloride gas or water vapour, $\mathrm{CuS}$ was the main phase associated with the corrosion product. The presence of chlorine induced pitting corrosion and perforation of the copper foil. Only minor amounts of $\mathrm{CuCl}_{2}$ were detected after the copper foil was exposed to sulphur vapour and hydrogen chloride gas at $80{ }^{\circ} \mathrm{C}$ to $140{ }^{\circ} \mathrm{C}$.

The exposure of copper foil to water vapour together with $\mathrm{S}_{2}$ resulted in the formation of a dendrite structured $\mathrm{CuS}$ with minor amounts of a copper oxysulphate phase (dolerophane). The reaction of both water vapour and sulphur vapour with copper at $140{ }^{\circ} \mathrm{C}$ changed the morphology of the corrosion product from $\mathrm{Cu}_{9} \mathrm{~S}_{8}$ to dendrites of covellite and dolerophane.

$\mathrm{Cu}_{2} \mathrm{~S}$ was only observed when copper foil at $140^{\circ} \mathrm{C}$ was exposed to hydrogen sulphide gas. The reaction between copper foil and hydrogen sulphide gas at low gas concentrations did not seem to have a strong effect on the corrosion rate compared to reactions of copper by sulphur vapour.

Corrosion rates ranging from $3.1 \mu \mathrm{m} / \mathrm{h}$ to as high as $9.2 \mu \mathrm{m} / \mathrm{h}$ were observed when copper foil was reacted with sulphur vapour between $65^{\circ} \mathrm{C}$ and $110^{\circ} \mathrm{C}$. Sulphidation of copper by sulphur vapour can therefore cause severe corrosion even at moderate temperatures. The corrosion rate decreased significantly above the melting point of sulphur $\left(112{ }^{\circ} \mathrm{C}\right)$, while above $112^{\circ} \mathrm{C}$ chlorine enhanced the corrosion rate significantly.

Sulphides that formed when copper foil reacted with sulphur vapour were friable and non-adherent to the copper. This had the consequence that the reproducibility of the corrosion experiments was good at short reaction times, but substantially poorer with longer exposure times as a result of crack formation and loss of the protective layer due to poor adherence of the scale.

It can be inferred from these laboratory scale experiments that the corrosion of copper coolers mainly proceeds through the reaction with $\mathrm{S}_{2}$, whereby a friable and nonadherent sulphide scale forms. This scale is prone to cracking and peeling off, which implies that corrosion of the copper cooler will proceed as long as the furnace remains in operation. Any chlorides in the feed to the furnace are potentially harmful to the cooler, as chlorine enhances the corrosion rate of copper with $\mathrm{S}_{2}$. Hydrogen sulphide 
does not seem to play a major role in the corrosion of copper coolers in PGM smelters.

\section{Acknowledgements}

The authors would like to thank Mintek for financial support.

\section{References:}

1. L.R. Nelson, J.M.A. Geldenhuis, B. Emery, M. de Vries, K. Joiner, J. Sarvinis, F.A. Stober, R. Sullivan, N. Voermann, C. Walker, B. Wasmund, Hatch Developments in furnace design in conjunction with smelting plants in Africa, in: RT Jones (Ed.), Southern African Pyrometallurgy, The Southern African Institute of Mining and Metallurgy, Johannesburg, 2006, pp. 417-436.

2. R. Hundermark, B. de Villiers, J. Ndlovu, Process description and short history of Polokwane smelter, in: RT Jones (Ed.), Southern African Pyrometallurgy, The Southern African Institute of Mining and Metallurgy, Johannesburg, 2006, pp. 35-42.

3. C. Pistorius, Confidential report, University of Pretoria, 2004.

4. L. Andrews, Base metal losses to furnace slag during processing of platinum bearing concentrates, Master's Thesis, University of Pretoria, South Africa, 2008.

5. M. Hopt, E. Rossouw, New opportunities - exhaustive monitored copper coolers for submerged arc furnaces, Journal of the Southern African Institute of Mining and Metallurgy, 106 (2006) 373-378.

6. L. Mabiza, An overview of PGM smelting in Zimbabwe-Zimplats Operations, in: RT Jones (Ed.), Southern African Pyrometallurgy, The Southern African Institute of Mining and Metallurgy, Johannesburg, 2006, pp. 63-75.

7. L.C. Woollacott, R.H. Eric, Mineral and Metal Extraction an Overview, The Southern African Institute of Mining and Metallurgy, Johannesburg, 1994.

8. P. Patnik, Handbook of Inorganic Chemicals, McGraw-Hill, 2003.

9. BM Thethwayo, Sulphidation of copper coolers in PGM smelters, Master's Thesis, University of Pretoria, South Africa, 2010.

10. R.S. Larson, A physical and mathematical model for the atmospheric sulphidation of copper by hydrogen sulphide, Journal of the Electrochemical Society 149 (2002) B40-B46.

11. T.T.M. Tran, C. Fiaud, A. Villanova, The atmospheric corrosion of copper by hydrogen sulphide in underground conditions, Corrosion Science 45 (2003) 2787-2802.

12. I. Bartkowicz, A. Stoklosa, Kinetics of copper sulphidation at temperatures 570K-1123K, Oxidation of Metals 25 (1986) 305-318.

13. R. Blachnik, A. Muller, The formation of $\mathrm{Cu}_{2} \mathrm{~S}$ from the elements II copper used in form of foils, Thermochimica Acta 366 (2001) 47-59.

14. A. Martinez, S. Toesca, Reactivity of copper-doped, brass plated steel cords with hydrogen sulphide, Reactivity of Solids 1 (1986) 263-273.

15. F. Gesmundo, Y. Niu, P. Castello, F. Viani, A.M. Huntz, W.T. Wu, The sulphidation of two-phase $\mathrm{Cu}-\mathrm{Ag}$ Alloys in $\mathrm{H}_{2}-\mathrm{H}_{2} \mathrm{~S}$ mixtures at $550-750^{\circ} \mathrm{C}$, Corrosion Science 38 (1996) 1295-1317. 
16. I. Bartkowicz, A. Stoklosa, Kinetics of copper, nickel, cobalt and iron sulfidation by a modified "pellet" method. The effect of reaction at metal/scale interface, Solid State Ionics, 23 (1987) 51-59.

17. T.T.M. Tran, C. Fiaud, E.M.M. Sutter, Oxide and sulphide layers on copper exposed to $\mathrm{H}_{2} \mathrm{~S}$ containing moist air, Corrosion Science 47 (2005) 1724-1737.

18. D.J. Vaughan, J.R. Craig, Mineral chemistry of metal sulfides, Cambridge University Press, Cambridge, 1978.

19. R.Z. Vracar, K.P. Cerovic, Thermodynamic analysis of copper (I) sulphide chlorination by calcium chloride in the presence of oxygen, Journal of the Serbian Chemical Society 64 (1999) 365-374.

20. W. Sesselmann, T.J. Chuang, The interaction of chlorine with copper II bulk diffusion, Surface Science 176 (1986) 67-90.

21. S. Brooks, D.B. Meadowcroft, The role of chlorine in the corrosion of mild and low alloy steels in low $\mathrm{pO}_{2}$, high $\mathrm{pS}_{2}$ environments, in: M.F. Rothman, (Ed.) High Temperature Corrosion in Energy Systems, Metallurgical Society of AIME, New York, 1985, pp. 515-527.

22. M. Reid, J. Punch, L.F. Garfias-Mesias, K. Shannon, S. Belochapkine, D.A. Tanner, Study of mixed flowing gas exposure of copper, Journal of the Electrochemical Society 155 (2008) C147-C153.

23. W.C. Lenahan, R. de L. Murray-Smith, Assay and Analytical Practice in the South African Mining Industry, Southern African Institute of Mining and Metallurgy Monograph Series M6, The Southern African Institute of Mining and Metallurgy, Johannesburg, 2001, pp. 176-177.

24. C.E. Schuster, M.G. Vangel, H.A. Schafft, Improved estimation of the resistivity of pure copper and electrical determination of thin copper film dimensions, Microelectronics Reliability 41 (2001) 239-252.

25. W. Steinhogl, G. Schindler, G. Steinlesberger, M. Training, M. Engelhardt, Comprehensive study of the resistivity of copper wires lateral dimensions of 100nm and smaller, Journal of Applied Physics 97 (2005) 023706-1 - 023706-7.

26. A. Dravnieks, H.J. McDonald, The zone of metal phase consumption in gasmetal reactions, Journal of the Electrochemical Society 94 (1948) 139-151.

27. D.R. Swinbourne, B. Harris, Kinetics of copper(I)sulphide chlorination. Transactions of the Institute of Mining and Metallurgy Section C 88 (1979) 9398.

28. K.T. Tezuka, W.C. Sheets, R. Kurihara, Y.J. Shan, H. Imoto, T.J. Marks, K.R. Poeppelmeier, Synthesis of covellite $(\mathrm{CuS})$ from the elements, Solid State Sciences 9 (2007) 95-99. 


\section{$\underline{\text { List of Figures }}$}

Figure 1: Temperature-composition diagram of condensed phases in the CopperSulphur system [18].

Figure 2: Average corrosion rate as a function of temperature when copper was exposed to sulphur vapour in the temperature range $65^{\circ} \mathrm{C}$ to $140{ }^{\circ} \mathrm{C}$ for 1 hour.

Figure 3: Thickness loss on copper foil as a function of exposure time for temperatures ranging from $65^{\circ} \mathrm{C}$ to $140{ }^{\circ} \mathrm{C}$ (sulphidation by sulphur vapour).

Figure 4: Thickness loss of copper foil as a function of exposure time in the temperature range $80{ }^{\circ} \mathrm{C}$ to $140{ }^{\circ} \mathrm{C}$ in sulphur vapour.

Figure 5: Thickness loss of a copper foil as a function of exposure time at $140{ }^{\circ} \mathrm{C}$ in sulphur vapour.

Figure 6: Thickness loss as a function of exposure time at varying temperatures (80 ${ }^{\circ} \mathrm{C}$ to $140^{\circ} \mathrm{C}$ ); when copper foil was exposed to both sulphur vapour and hydrogen chloride gas.

Figure 7: BSE images of the cross section of the corrosion product formed during sulphidation with sulphur vapour at a) $80{ }^{\circ} \mathrm{C}$, b) $\left.110{ }^{\circ} \mathrm{C}, \mathrm{c}\right) 140{ }^{\circ} \mathrm{C}$ and d) 80 ${ }^{\circ} \mathrm{C}-140{ }^{\circ} \mathrm{C}$.

Figure 8: BSE image of the cross-section of the copper foil after exposure to both sulphur vapour and hydrogen chloride gas at $140{ }^{\circ} \mathrm{C}$.

Figure 9: BSE image of the corrosion product which formed when copper was reacted from $80{ }^{\circ} \mathrm{C}$ to $140{ }^{\circ} \mathrm{C}$ in a sulphur vapour and water vapour atmosphere.

Figure 10: BSE image of a cross-section of the copper foil after exposure to hydrogen sulphide gas at $140{ }^{\circ} \mathrm{C}$.

\section{List of Tables}

Table 1: Summary of the phases that formed in the corrosion products 
Figure 1: Temperature-composition diagram of condensed phases in the Copper-Sulphur system

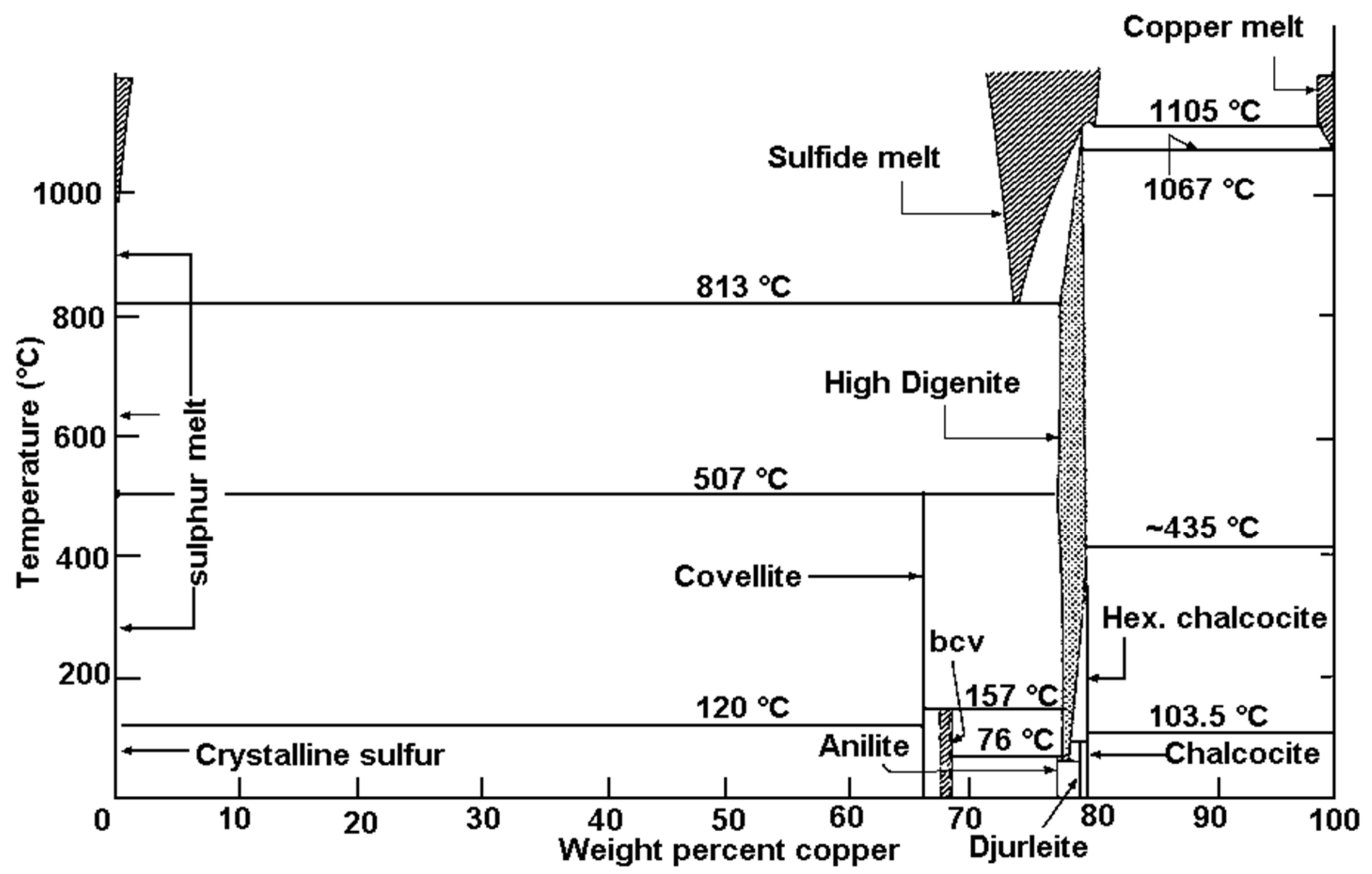


Figure 1: Average corrosion rate as a function of temperature when copper was exposed to sulphur vapour in the temperature range $65^{\circ} \mathrm{C}$ to $140{ }^{\circ} \mathrm{C}$ for 1 hour.

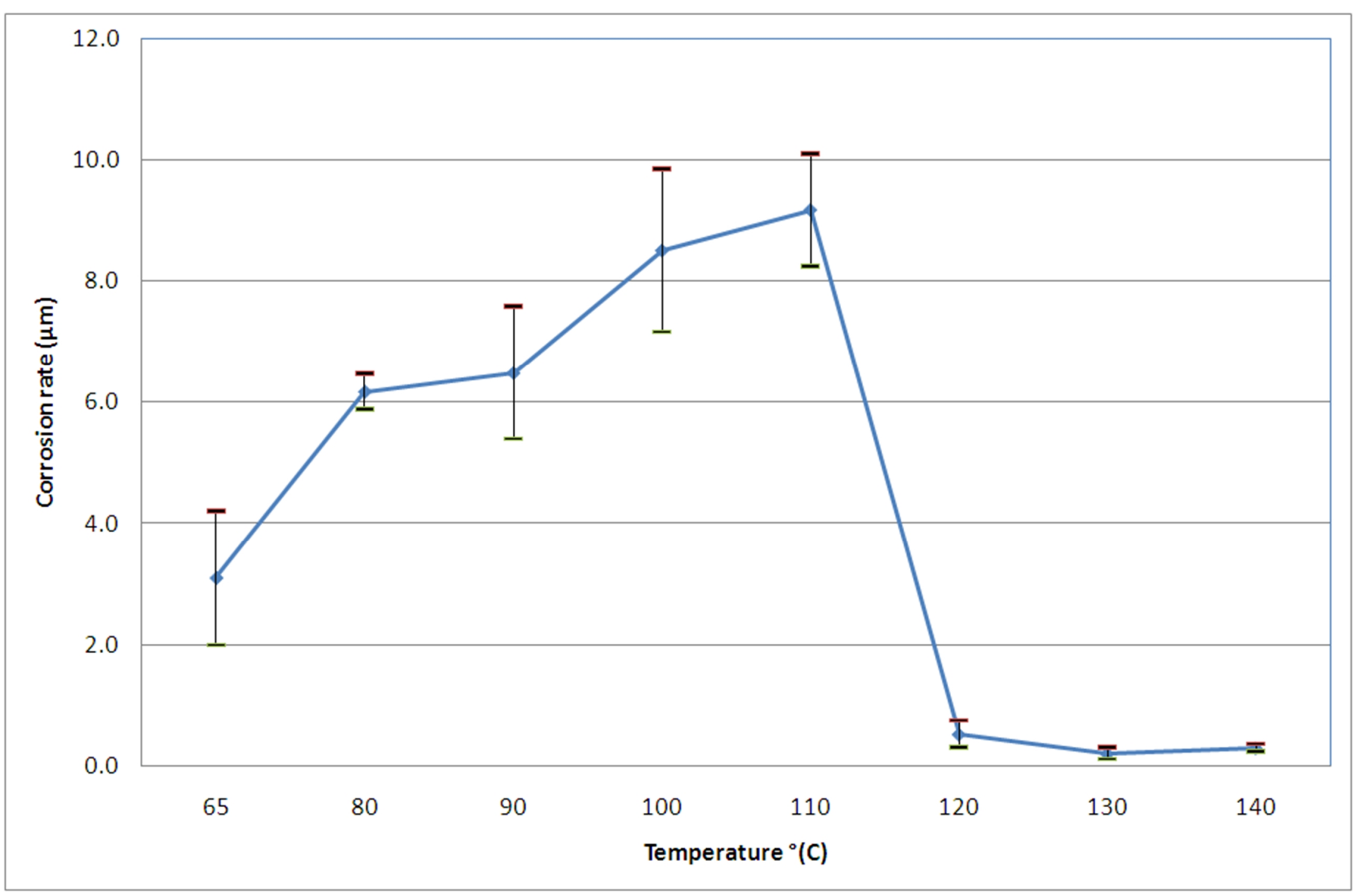


Figure 2: Thickness loss on copper foil as a function of exposure time for temperatures ranging from $65{ }^{\circ} \mathrm{C}$ to $140{ }^{\circ} \mathrm{C}$ (sulphidation by sulphur vapour).

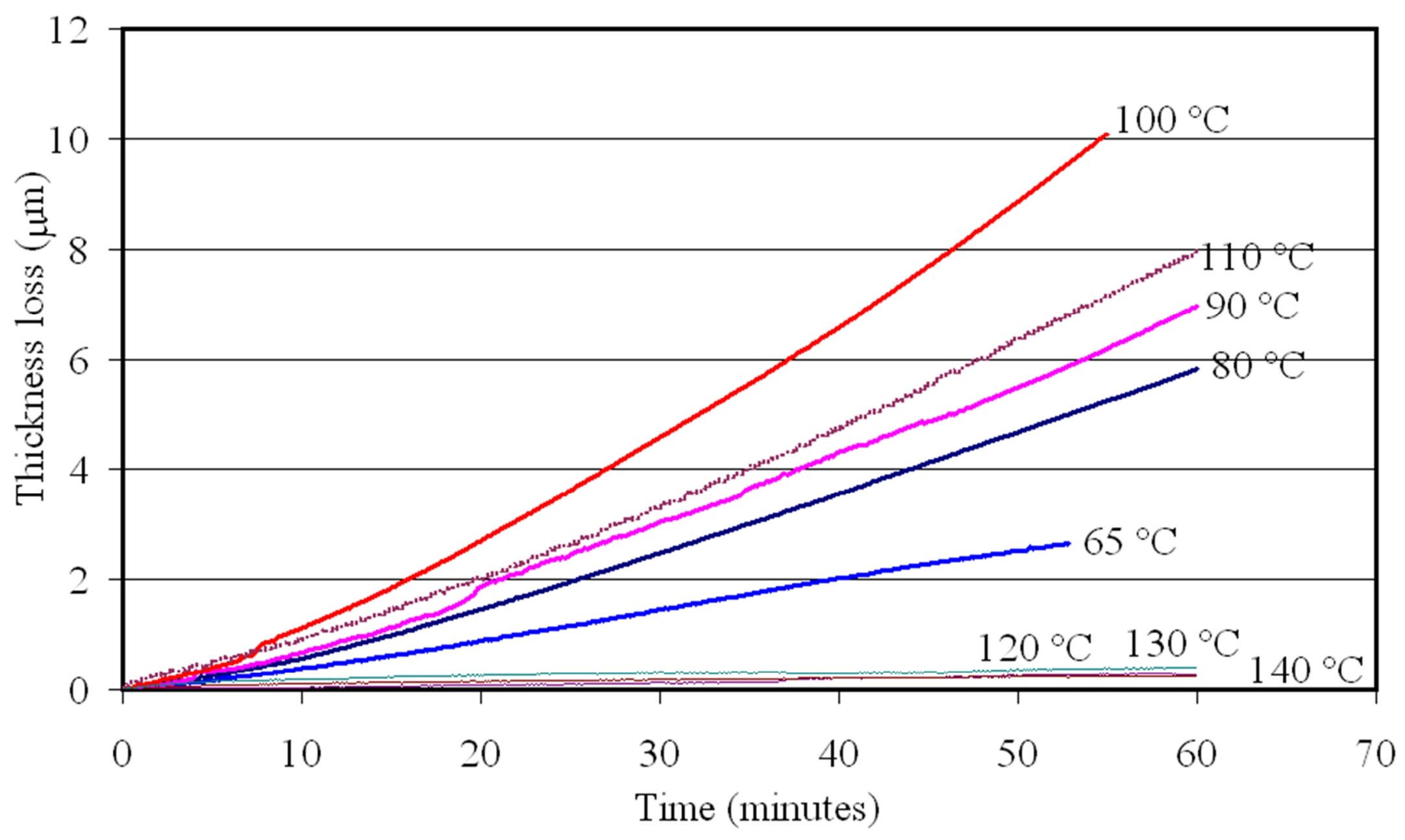


Figure 3: Thickness loss of copper foil as a function of exposure time in the temperature range $80^{\circ} \mathrm{C}$ to $140{ }^{\circ} \mathrm{C}$ in sulphur vapour.

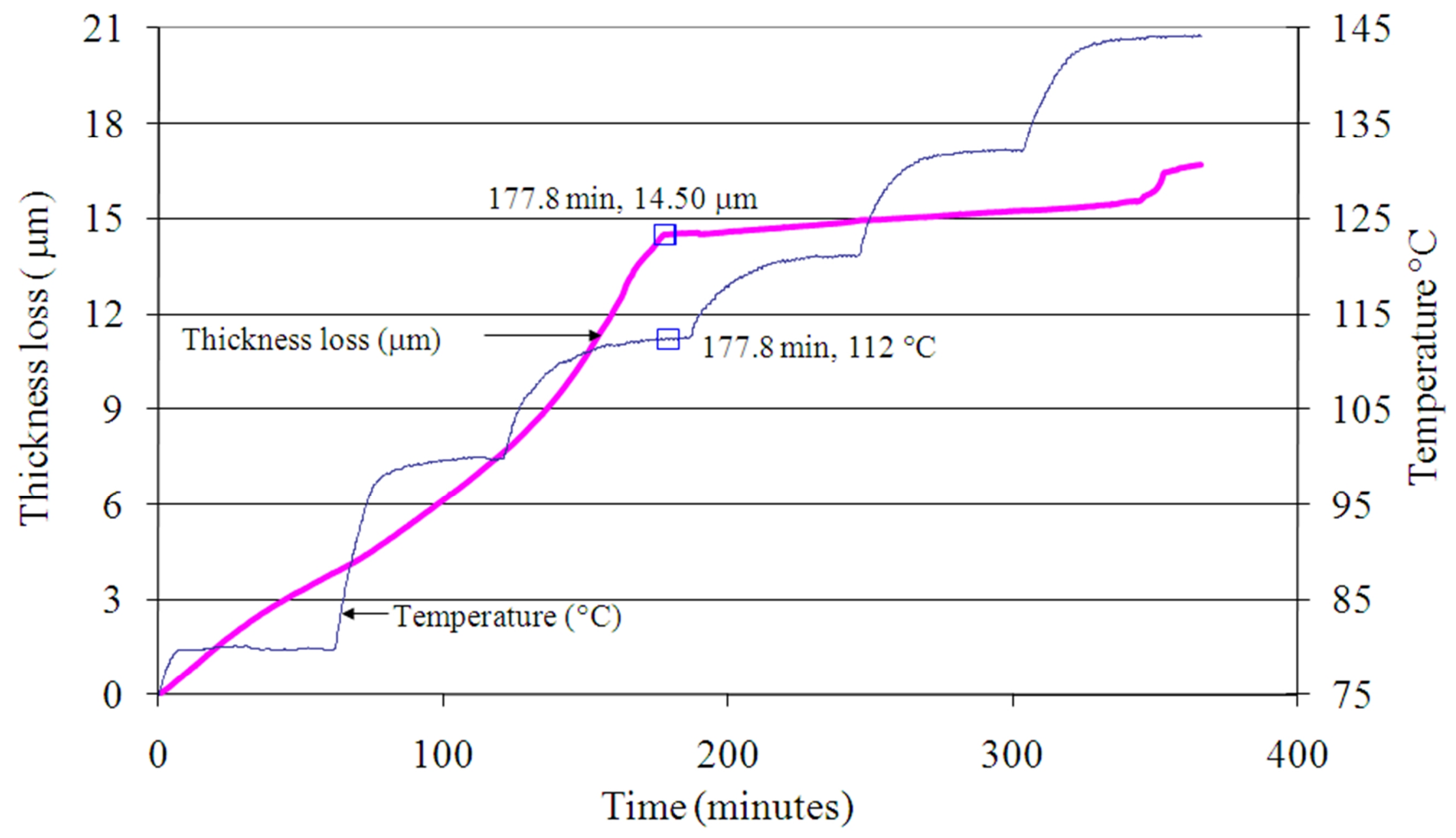


Figure 4: Thickness loss of a copper foil as a function of exposure time at $140^{\circ} \mathrm{C}$ in sulphur vapour.

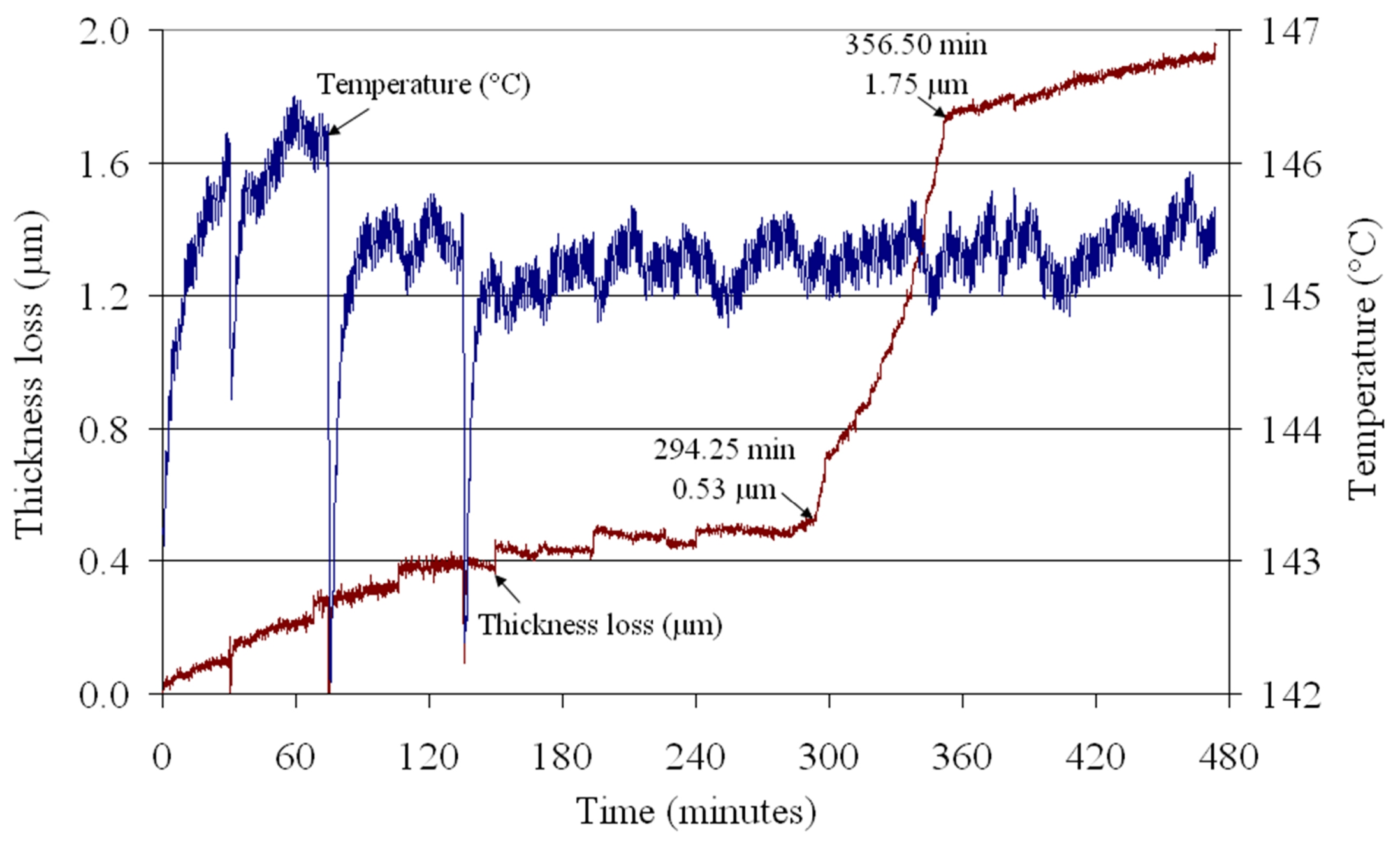


Figure 5: Thickness loss as a function of exposure time at varying temperatures $\left(80^{\circ} \mathrm{C}\right.$ to $\left.140{ }^{\circ} \mathrm{C}\right)$ when copper foil was exposed to both sulphur vapour and hydrogen chloride gas.

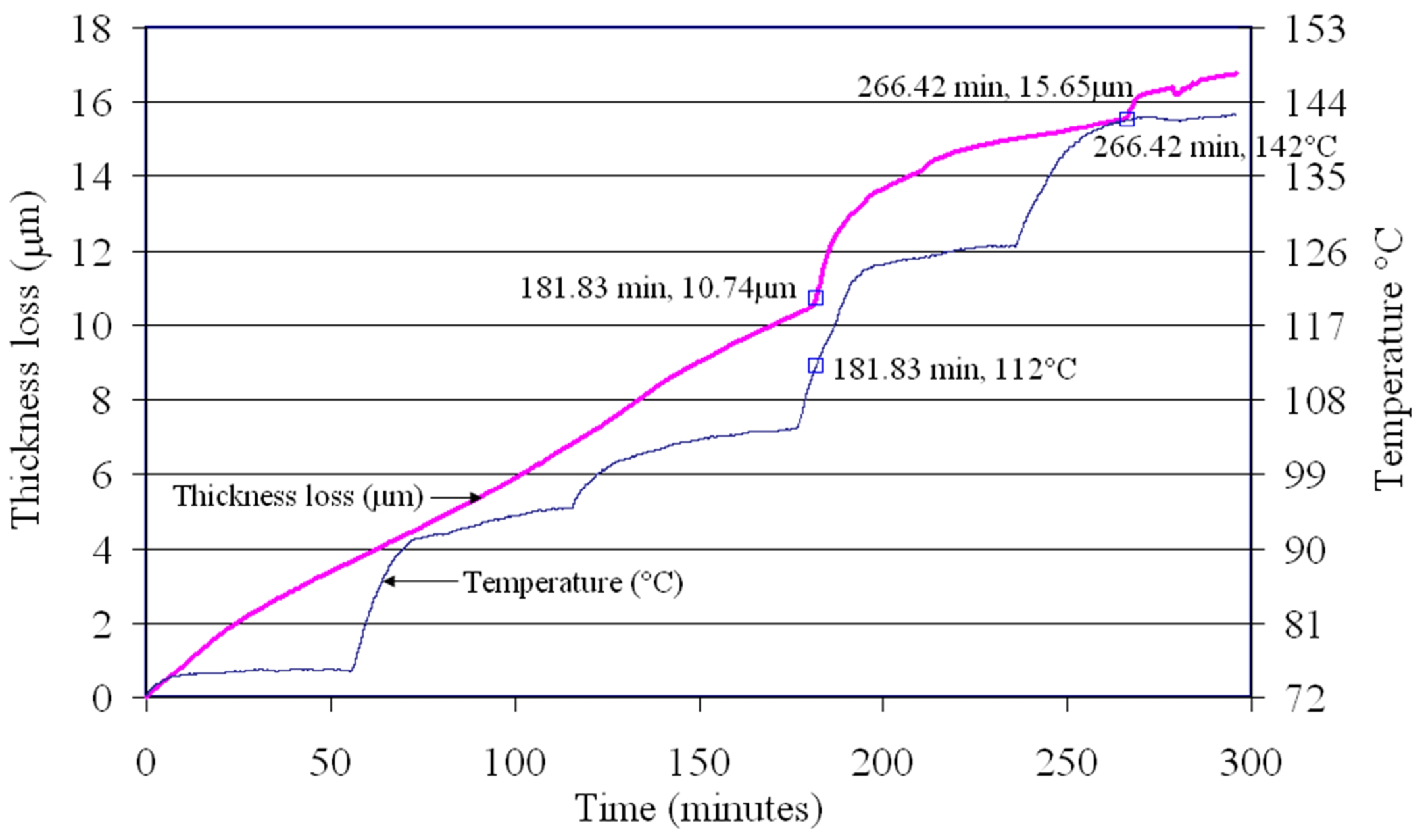


Figure 6: BSE images of the cross section of the corrosion product formed during sulphidation with sulphur vapour at a) $80{ }^{\circ} \mathrm{C}$, b) $110^{\circ} \mathrm{C}$, c) $140^{\circ} \mathrm{C}$ and d) $80^{\circ} \mathrm{C}-140^{\circ} \mathrm{C}$.
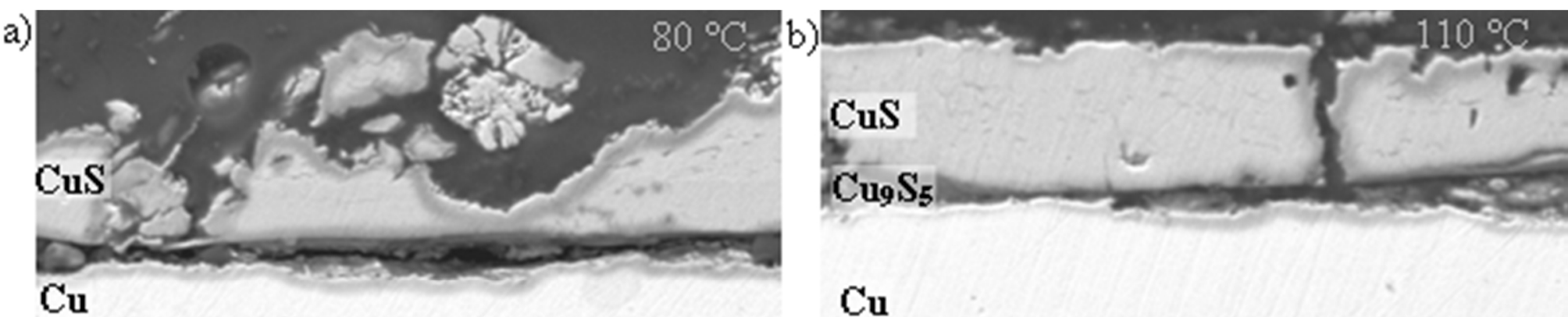

$\mathrm{Cu}$
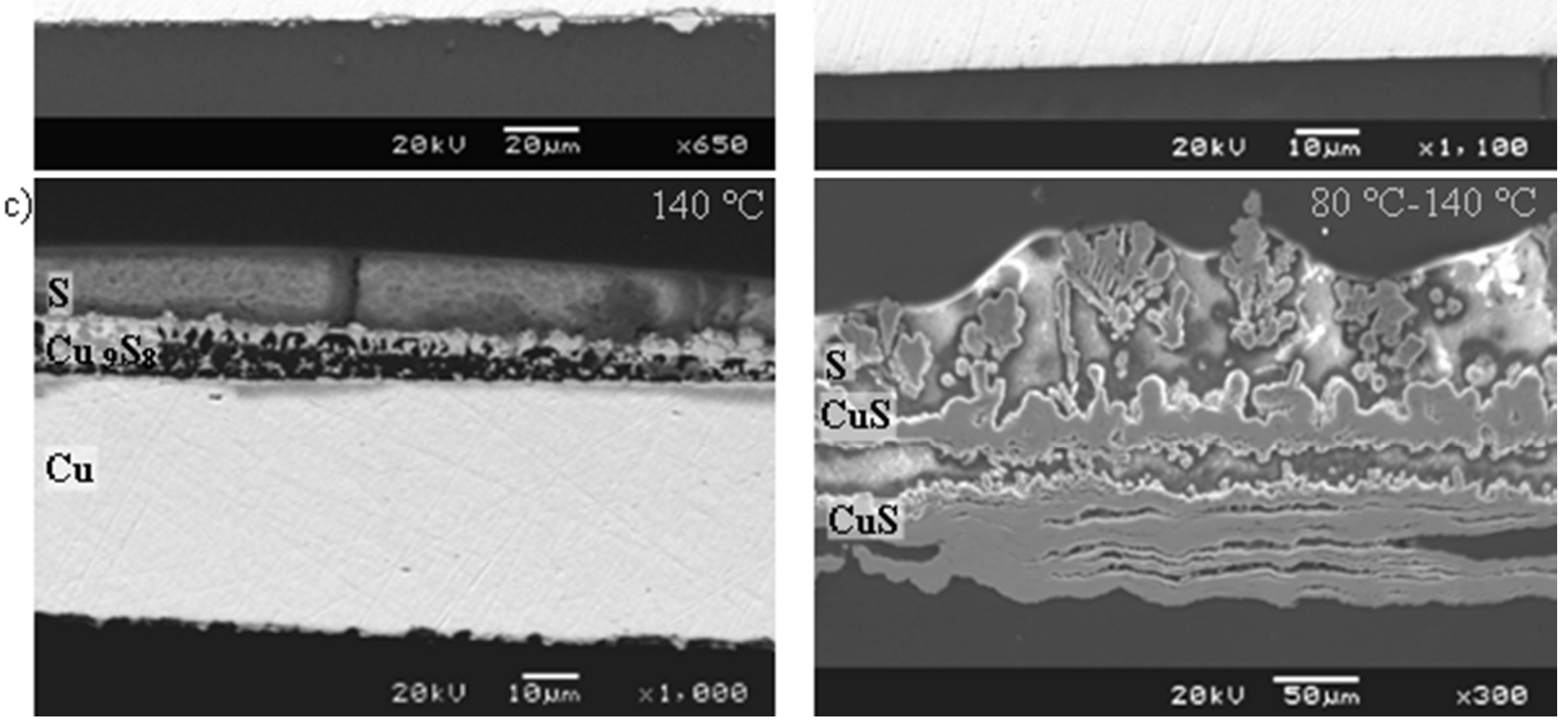
Figure 7: BSE image of the cross-section of the copper foil after exposure to both sulphur vapour and hydrogen chloride gas at $140{ }^{\circ} \mathrm{C}$.

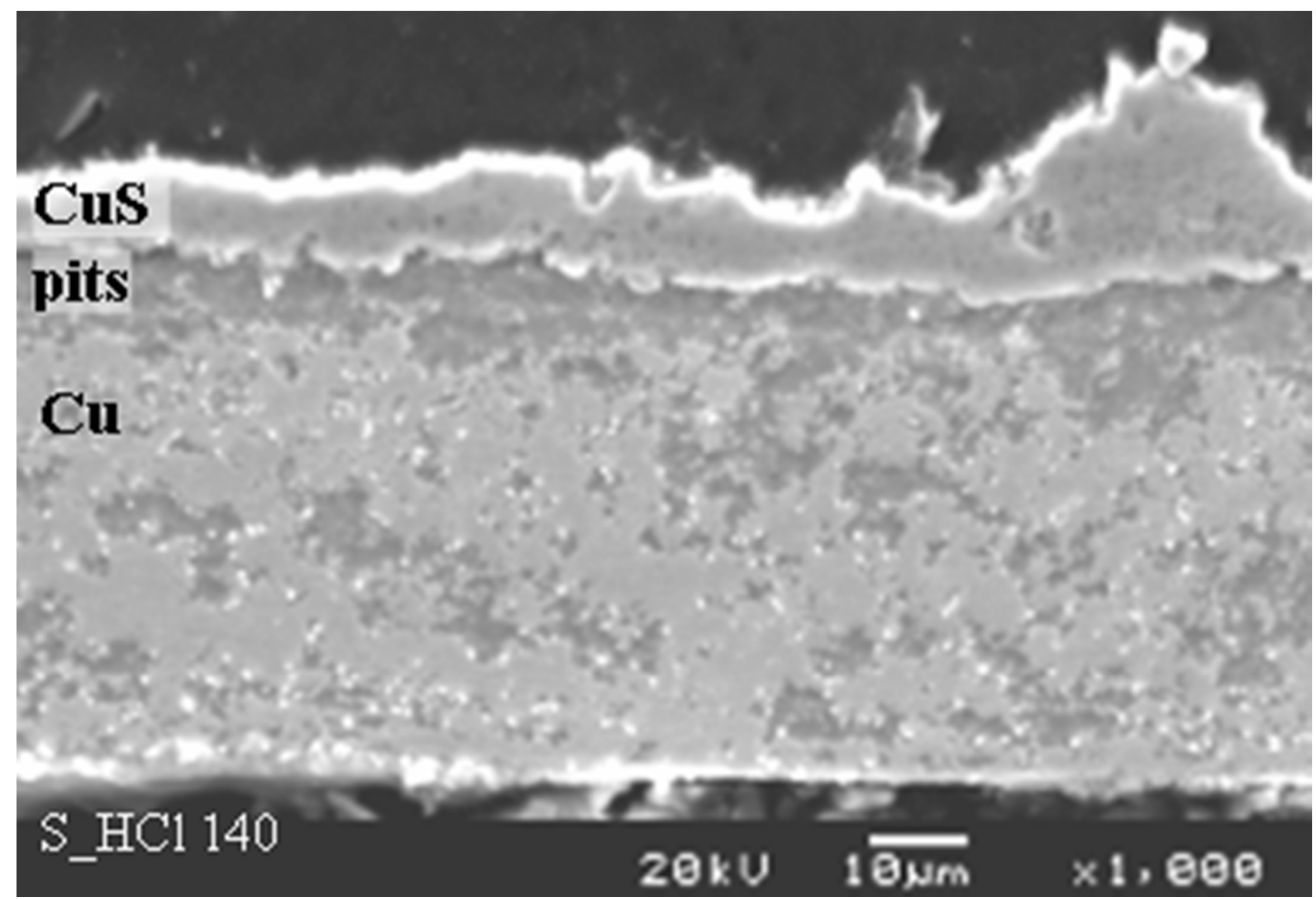


Figure 8: BSE image of the corrosion product which formed when copper was reacted from $80^{\circ} \mathrm{C}$ to $140{ }^{\circ} \mathrm{C}$ in a sulphur vapour and water vapour atmosphere.

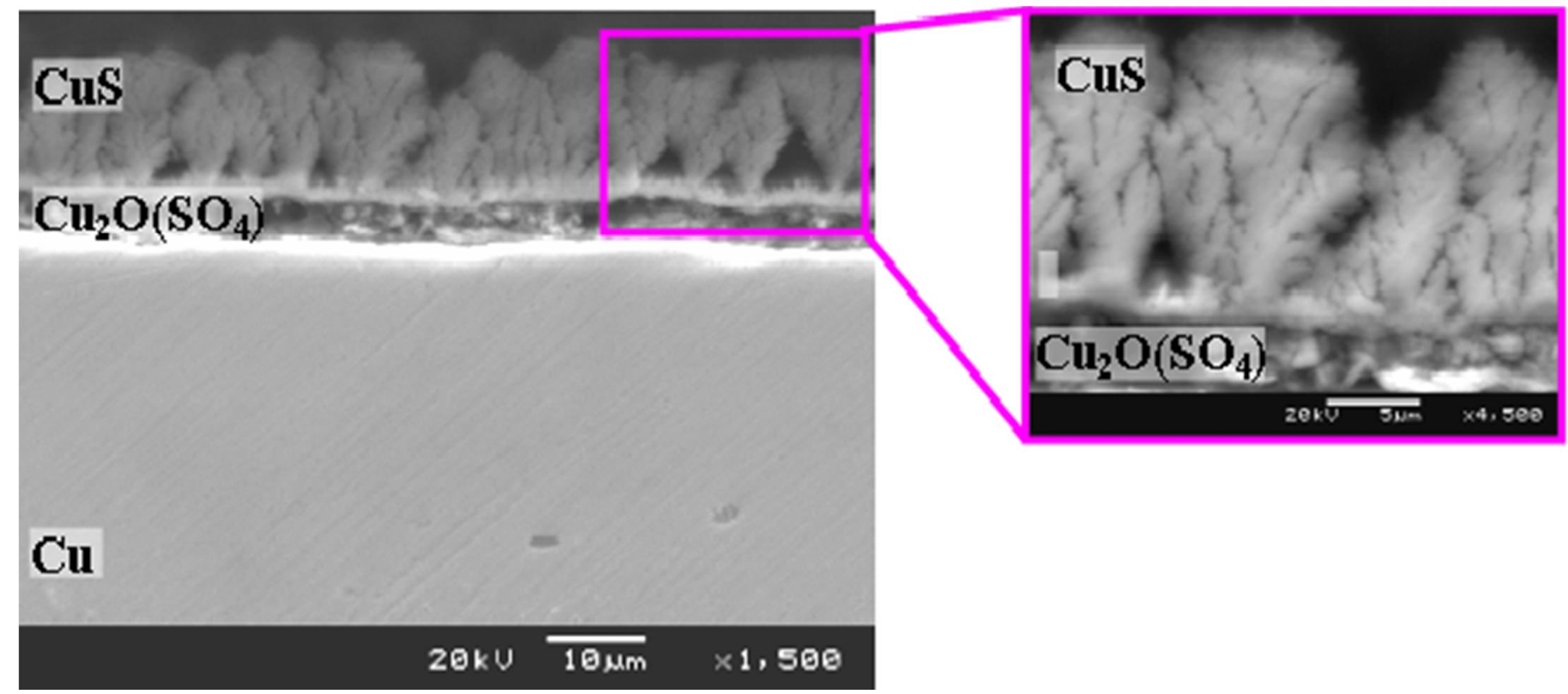


Figure 9: BSE image of a cross-section of the copper foil after exposure to hydrogen sulphide gas at $140{ }^{\circ} \mathrm{C}$.

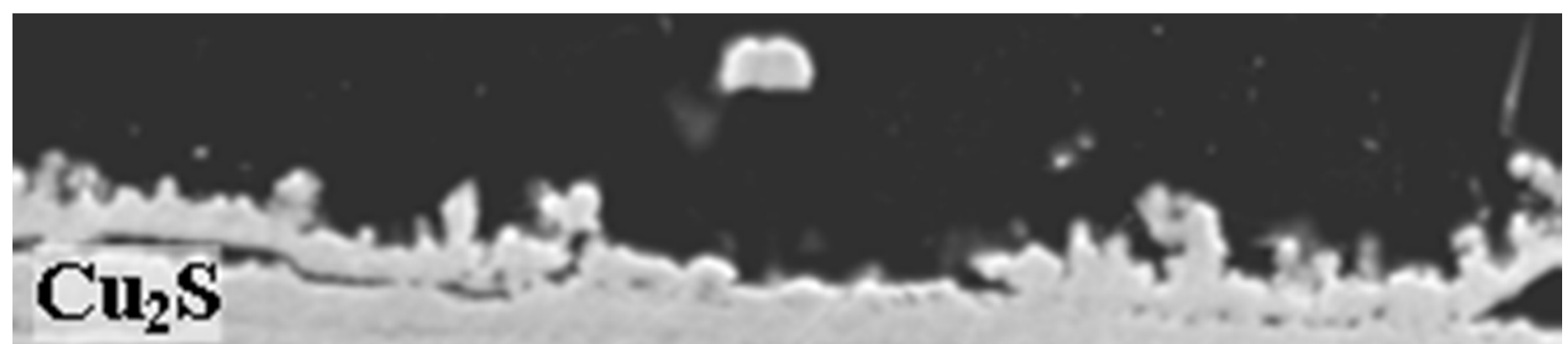
pits

\section{$\mathrm{Cu}$}

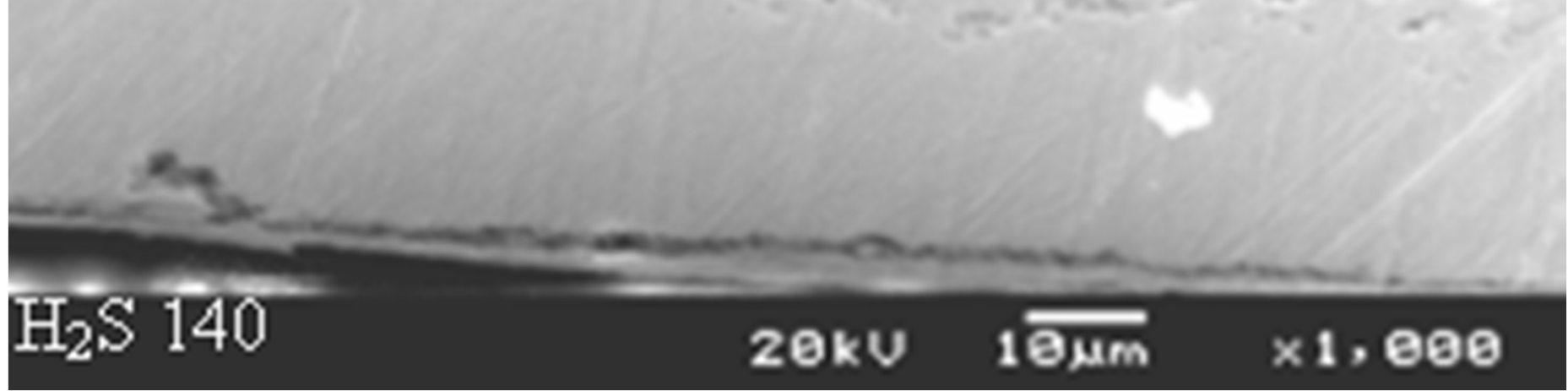


Table 1: Summary of the phases that formed in the corrosion products

\begin{tabular}{|l|l|l|}
\hline Corroding gas & Copper foil temperature & Corrosion product(s) \\
\hline & & \\
\hline Sulphur vapour & $80^{\circ} \mathrm{C}$ & $\mathrm{CuS}+\mathrm{S}$ (powder) \\
\hline Sulphur vapour & $110^{\circ} \mathrm{C}$ & $\mathrm{CuS}+\mathrm{Cu}_{9} \mathrm{~S}_{5}$ \\
\hline Sulphur vapour & $140^{\circ} \mathrm{C}$ & $\mathrm{CuS}+\mathrm{Cu}_{9} \mathrm{~S}_{8}+\mathrm{S}$ (molten) \\
\hline & & \\
\hline Sulphur vapour & $80^{\circ} \mathrm{C}$ to $140^{\circ} \mathrm{C}$ & $\mathrm{CuS}+\mathrm{S}$ (molten) \\
\hline & & \\
\hline Sulphur $+\mathrm{HCl}$ & $140^{\circ} \mathrm{C}$ & $\mathrm{CuS}+\mathrm{S}$ \\
\hline Sulphur $+\mathrm{HCl}$ & $80^{\circ} \mathrm{C}$ to $140^{\circ} \mathrm{C}$ & $\mathrm{CuS}+\mathrm{S}+\mathrm{CuCl}_{2}$ \\
\hline Sulphur $+\mathrm{H}_{2} \mathrm{O}$ & $140^{\circ} \mathrm{C}$ & $\mathrm{CuS}+\mathrm{S}+\mathrm{Cu}_{2} \mathrm{O}_{\left(\mathrm{SO}_{4}\right)}$ \\
\hline $\mathrm{H}_{2} \mathrm{~S}$ & $140^{\circ} \mathrm{C}$ & $\mathrm{Cu} 2$ \\
\hline
\end{tabular}

